\title{
Article \\ Changes of Growth and Inflorescence Initiation by Exogenous Gibberellic Acid 3 and 6-Benzylaminopurine Application in Phalaenopsis Orchids
}

\author{
Hyo Beom Lee ${ }^{1,2}$, Nam Hyun Im ${ }^{1}$, Seong Kwang An ${ }^{1}$ [D and Ki Sun Kim ${ }^{1,2, *}$ \\ 1 Department of Horticultural Science and Biotechnology, Seoul National University, Seoul 08826, Korea; \\ hyobumi1003@snu.ac.kr (H.B.L.); nhim4774@snu.ac.kr (N.H.I.); ahnsungkwang@snu.ac.kr (S.K.A.) \\ 2 Research Institute of Agricultural and Life Sciences, Seoul National University, Seoul 08826, Korea \\ * Correspondence: kisun@snu.ac.kr
}

Citation: Lee, H.B.; Im, N.H.; An, S.K.; Kim, K.S. Changes of Growth and Inflorescence Initiation by Exogenous Gibberellic $\mathrm{Acid}_{3}$ and 6-Benzylaminopurine Application in Phalaenopsis Orchids. Agronomy 2021,

11, 196. https://doi.org/

10.3390/agronomy11020196

Academic Editor: Anastasios Darras Received: 13 November 2020

Accepted: 18 January 2021

Published: 20 January 2021

Publisher's Note: MDPI stays neutral with regard to jurisdictional claims in published maps and institutional affiliations.

Copyright: (c) 2021 by the authors. Licensee MDPI, Basel, Switzerland. This article is an open access article distributed under the terms and conditions of the Creative Commons Attribution (CC BY) license (https:// creativecommons.org/licenses/by/ $4.0 /)$.
Abstract: This study was conducted to observe the effects of exogenous gibberellic acid ${ }_{3}\left(\mathrm{GA}_{3}\right)$ and 6-benzylaminopurine (BAP) treatments on the growth and inflorescence initiation of Phalaenopsis and to determine whether hormonal applications can substitute for low-temperature exposure for floral transition. Phalaenopsis Queen Beer 'Mantefon' clones were treated with no hormones (control), GA $100 \mathrm{mg} / \mathrm{L}, \mathrm{GA}_{3} 200 \mathrm{mg} / \mathrm{L}, \mathrm{BAP} 100 \mathrm{mg} / \mathrm{L}$, and GA $100 \mathrm{mg} / \mathrm{L}+\mathrm{BAP} 100 \mathrm{mg} / \mathrm{L}$ by foliar spray. The treatments were carried at $28^{\circ} \mathrm{C}$ for vegetative growth and $20{ }^{\circ} \mathrm{C}$ for forcing, respectively. At $28^{\circ} \mathrm{C}$ of vegetative temperature, all exogenous hormonal treatments did not induce inflorescence initiation, but lateral shoots were observed in BAP-treated plants even though this plant is a monopodial orchid. $\mathrm{GA}_{3}$ significantly increased leaf length and decreased leaf width, and consequently increased length:width $(\mathrm{L}: \mathrm{W})$ ratio compared with the control and BAP alone. The trend grew as $\mathrm{GA}_{3}$ concentration increased. Also, the $\mathrm{GA}_{3}$ increased stem length and decreased stem diameter. At $20^{\circ} \mathrm{C}$ of forcing temperature, L:W ratio responded similarly to $28^{\circ} \mathrm{C}$ in $\mathrm{GA}_{3}$ treatments, but leaf size was smaller than for the control or BAP alone. BAP accelerated inflorescence emergence and significantly increased inflorescence numbers, whereas $\mathrm{GA}_{3}$ and $\mathrm{GA}_{3}+\mathrm{BAP}$ slightly delayed inflorescence emergence. $\mathrm{GA}_{3}$ significantly promoted new leaf development at $20{ }^{\circ} \mathrm{C}$ of forcing condition. These results indicated that cytokinin was associated with the break of axillary vegetative and inflorescence meristems and exogenous $\mathrm{GA}_{3}$ spray did not improve inflorescence initiation in Phalaenopsis. Although exogenous hormonal application did not substitute for low-temperature exposure, it showed a possibility in promoting the growth and inflorescence initiation.

Keywords: cytokinin; Doritaenopsis; floral transition; gibberellin; plant hormone

\section{Introduction}

Phalaenopsis is a monopodial orchid and includes approximately 60-70 species [1]. Phalaenopsis has unique flower shapes and colors with a long flowering time. There are many generic hybrids (e.g., Doritaenopsis; Phalaenopsis $\mathrm{x}$ Doritis) with diverse variations in flowers [2]. Because of these characteristics, Phalaenopsis is one of the most popular floricultural crops throughout the world and is cultivated commercially in many countries.

Plants perceive environmental changes, which in turn cause their floral transition. Temperature is an important environmental factor in many species and Phalaenopsis inflorescence initiation is also mainly controlled by exposure to temperature drop. Although Phalaenopsis originates from tropical and subtropical regions [3], common hybrids in this genus require several weeks of a prolonged period below $25^{\circ} \mathrm{C}$ for inflorescence initiation, whereas temperatures above $28^{\circ} \mathrm{C}$ prevent the floral transition [4]. Exposure to relatively low temperature from high temperature enables flowering time control and year-round cultivation. Phalaenopsis has meristems capable of developing into inflorescences in the stem 
at the base of each leaf [5]. These meristems have eco-dormancy, which can be eliminated by low-temperature exposure [6,7].

Plant hormones play important roles in many developmental processes including morphogenesis, dormancy, flowering, etc. [8-10]. Among plant hormones, gibberellic acids (GAs) are involved in bolting of vernalization-requiring or long-day plants [11,12], and DELLA-mediated GA signaling is well understood [13]. In Phalaenopsis, GA contents in inflorescences increase simultaneously during inflorescence development and exogenous GA injection can induce flower primordia at vegetative high temperature, which normally inhibits flower induction [14-16]. The GA injection, however, does not induce inflorescence initiation [17]. Huang et al. [18] referred that the GA pathway may play a role in regulating inflorescence initiation in transcriptomic analysis. Another study, however, did not observe upregulations in transcription of genes related to GA biosynthesis at forcing temperature [19]. Thus, GA's role as a key regulator in Phalaenopsis floral transition is still unclear, including whether or not it can induce inflorescence initiation without low-temperature exposure.

Cytokinin (CK) is also considered to act as a stimulus for floral transition [20]. In rapeseed (Brassica napus), an increase of CK levels was observed in reproductive plants when compared with vegetative plants [21]. CK also promoted flowering via transcriptional activation of a paralogue of FLOWERING LOCUS T (FT), TWIN SISTER OF FT (TSF), in Arabidopsis [22]. In Dendrobium nobile orchid, exogenous CK treatment could induce inflorescence initiation without vernalization [23]. CKs remained in active forms under forcing condition, while the CKs in leaves were converted from active to inactive glucoside forms at vegetative high temperature in Phalaenopsis [24]. Exogenous 6-benzylaminopurine (BAP) spray during a low-temperature exposure accelerated inflorescence emergence and increased inflorescence numbers $[25,26]$, and inflorescence length decreased with increasing BAP concentrations [27]. Also, CKs can be used in callus formation and shoot regeneration for vegetative propagation from inflorescences in Phalaenopsis [28-30]. To our knowledge, however, there is no data verifying whether exogenous CK treatment can substitute for low-temperature requirement in Phalaenopsis floral transition.

Long cultivation time and a cooling requirement for inflorescence initiation demand high production costs in Phalaenopsis production. Alternative techniques that replace temperature-induced floral transition can save energy costs and improve production rate in Phalaenopsis [6,31]. Plant hormones and its synthetic compounds have been widely used in the horticultural industry for a long time. The use of the compounds can provide insights into further development in Phalaenopsis cultivation. However, as mentioned above, there is a lack of information about the roles of GAs and CKs in Phalaenopsis. Also, the effects of these hormones on growth characteristics during a vegetative period have not been discussed yet. In this study, $\mathrm{GA}_{3}$ and BAP were sprayed under vegetative and forcing conditions to observe their effects on the growth and inflorescence initiation of Phalaenopsis and to determine whether the exogenous hormonal application can substitute for low-temperature requirements in floral transition.

\section{Materials and Methods}

\subsection{Plant Materials and Growth Conditions}

Fifteen-month-old Phalaenopsis Queen Beer 'Mantefon' clones transplanted into $10 \mathrm{~cm}$ (approximately $500 \mathrm{~mL}$ volume) plastic pots filled with 100\% sphagnum moss were purchased from a commercial grower (Samhyeon Orchid Farm, Goyang, Korea). To prevent premature flowering, these plants were acclimatized for four weeks in environmentcontrolled growth chambers (HB-301MP; Hanbaek Scientific Co., Bucheon, Korea). Temperature and relative humidity were maintained at $28 \pm 1{ }^{\circ} \mathrm{C}$ and $60 \% \pm 10 \%$, respectively. The photoperiod was $12 \mathrm{~h}$ with $130 \pm 10 \mu \mathrm{mol} \cdot \mathrm{m}^{-2} \cdot \mathrm{s}^{-1}$ photosynthetic photon flux density (PPFD) provided by $250 \mathrm{~W}$ metal halide lamps (Han Young Electrics Co., Gwangju, Korea). Plants were fertigated once a week with a water-soluble fertilizer (electrical conductivity $0.8 \mathrm{mS} \cdot \mathrm{cm}^{-1}$, Hyponex professional 20N-20P-20K; Hyponex Japan, Osaka, Japan) by hand- 
drip irrigation. At the end of the acclimatization period, the mean plant span was $27.1 \mathrm{~cm}$ with 5-6 fully developed leaves.

\subsection{Exogenous $\mathrm{GA}_{3}$ and BAP Treatment under Vegetative Condition}

After acclimatizing, plants were treated with five different experimental combinations: no hormones (distilled water; control), GA 3 (Duchefa Biochemie, Haarlem, The Netherlands) $100 \mathrm{mg} / \mathrm{L}, \mathrm{GA}_{3} 200 \mathrm{mg} / \mathrm{L}, \mathrm{BAP}$ (6-Benzylaminopurine, Duchefa Biochemie, Haarlem, The Netherlands) $100 \mathrm{mg} / \mathrm{L}$, and $\mathrm{GA}_{3} 100 \mathrm{mg} / \mathrm{L}+\mathrm{BAP} 100 \mathrm{mg} / \mathrm{L}$. Just prior to foliar spray, $5 \mathrm{~mL}$ of $\mathrm{GA}_{3}$ and BAP solutions dissolved in $100 \%$ ethanol and $1 \mathrm{M} \mathrm{NaOH}$ respectively, were blended with distilled water and 0.1\% Tween-20 (P1379, Sigma-Aldrich Korea Ltd., Yongin, Korea). Each plant received 20-25 mL of each solution and the solutions were treated two times with a one-week interval. There were three replications per each treatment and each replication contained five plants. After treatment, plants were placed in a $28^{\circ} \mathrm{C}$ growth chamber (average temperature $28.4^{\circ} \mathrm{C}$ ) for 15 weeks. All other cultivation conditions were maintained at the same levels as during the acclimatization period. Completely randomized design was used in this experiment.

\subsection{Exogenous $\mathrm{GA}_{3}$ and BAP Treatment under Forcing Condition}

Treatment solutions and methods were the same as described in Section 2.2. After treatment, plants were placed in a $20{ }^{\circ} \mathrm{C}$ growth chamber (average temperature $19.5^{\circ} \mathrm{C}$ ) for 15 weeks. There were three replications per each treatment and each replication contained five plants. All other cultivation conditions were maintained at the same levels as during the acclimatization period. Completely randomized design was used in this experiment.

\subsection{Data Collection and Statistical Analysis}

After 15 weeks at $28{ }^{\circ} \mathrm{C}$ (vegetative condition), the number of new leaves (leaves longer than $0.5 \mathrm{~cm}$ that developed after treatments), length and width of the uppermost mature leaf, stem length and diameter, and percent of plants with visible inflorescence (VI, flower-stalk longer than $0.5 \mathrm{~cm}$ ) were measured and the ratio between leaf length $(\mathrm{L})$ and width (W) (L:W ratio) was calculated. Under $20^{\circ} \mathrm{C}$ forcing condition, the number of new leaves, length and width of the uppermost mature leaf, a ratio between leaf length and width, and percent of plants with VI were measured after 15 weeks of temperature treatment, and the days to VI and number of VIs were also counted every day during the experiment period. Statistical analysis was performed using analysis of variance (ANOVA) in SAS (Windows version 9.3; SAS Institute Inc., Cary, NC, USA). A comparison of parameters among treatment groups was performed by Tukey's honestly significant difference (HSD) test for evaluating the growth and flowering characteristics with $\alpha=0.05$ as the threshold for statistical significance. Graph module analyses were performed using SigmaPlot software version 10.0 (Systat Software, Inc., Chicago, IL, USA).

\section{Results}

\subsection{Growth Responses by Exogenous $G A_{3}$ and BAP Treatment}

Under the $28^{\circ} \mathrm{C}$ vegetative condition, $\mathrm{GA}_{3}$ significantly increased leaf length $(p<0.001)$ and decreased leaf width $(p<0.001)$ (Table 1$)$. Consequently, a L:W ratio $(p<0.001)$ increased compared with the no hormone and BAP alone. Similarly, stem length $(p<0.001)$ and diameter $(p<0.001)$ increased and decreased respectively, by the exogenous $\mathrm{GA}_{3}$ treatments. As the $\mathrm{GA}_{3}$ concentration increased, the L:W ratio increased significantly. When the parameters were compared between plants with no hormone and BAP alone, there was no significant difference, although the leaf length was slightly shorter in BAP-treated plants. The mixed treatment of $\mathrm{GA}_{3}$ and BAP yielded a reduced L:W ratio and stem length but also increased leaf width and stem diameter compared with the $\mathrm{GA}_{3}$ treatments. The BAP treatment also induced lateral shoots emerged from axillary meristems (Figure 1). Of the plants, $68.3 \%$ had one or two lateral shoots. No other treatments resulted in lateral shoots. Under the $20^{\circ} \mathrm{C}$ forcing condition, although the leaf length $(p<0.05)$ and width $(p<0.001)$ 
were shorter in $\mathrm{GA}_{3}$ treatments than the no hormone and BAP alone, the $\mathrm{L}: \mathrm{W}$ ratio $(p<0.01)$ still slightly increased, similar to the results under the $28^{\circ} \mathrm{C}$ vegetative condition.

Table 1. Growth characteristics of Phalaenopsis Queen Beer 'Mantefon' treated with exogenous gibberellic acid ${ }_{3}\left(\mathrm{GA}_{3}\right)$ and 6-benzylaminopurine (BAP) at either $28^{\circ} \mathrm{C}$ (vegetative condition) or $20^{\circ} \mathrm{C}$ (forcing condition) for 15 weeks.

\begin{tabular}{|c|c|c|c|c|c|c|}
\hline Treatment & Leaf Length $(\mathrm{cm})$ & Leaf Width $(\mathrm{cm})$ & $\mathrm{L}: \mathrm{W}$ ratio & Lateral Shoot (\% of Plants) & Stem Length $(\mathrm{cm})$ & Stem Diameter (mm) \\
\hline \multicolumn{7}{|c|}{ Vegetative condition at $28^{\circ} \mathrm{C}$} \\
\hline Control & $23.1 b c^{z}$ & $8.2 \mathrm{a}$ & $2.8 \mathrm{~d}$ & $0 \mathrm{~b}$ & $6.8 \mathrm{c}$ & $17.1 \mathrm{a}$ \\
\hline GA100 & $27.0 \mathrm{a}$ & $5.7 \mathrm{~b}$ & $4.8 \mathrm{~b}$ & $0 \mathrm{~b}$ & $9.1 \mathrm{a}$ & $13.7 \mathrm{C}$ \\
\hline GA200 & $28.0 \mathrm{a}$ & $5.1 b$ & $8.5 \mathrm{a}$ & $0 b$ & $9.6 a$ & $12.6 \mathrm{~d}$ \\
\hline GA100 + BAP100 & $25.3 \mathrm{ab}$ & $7.2 \mathrm{a}$ & $3.5 \mathrm{c}$ & $0 \mathrm{~b}$ & $7.9 \mathrm{~b}$ & $15.2 b$ \\
\hline BAP100 & $20.4 c$ & $8.3 \mathrm{a}$ & $2.4 \mathrm{~d}$ & $68.3 a$ & $6.6 c$ & $17.1 \mathrm{a}$ \\
\hline Significance & $* * *$ & $-1 * *$ & ${ }^{* * *}$ & $* * *$ & $* * *$ & $* * *$ \\
\hline$-0---$ & ---- & ---- & $\overline{F o r c i n g} \overline{\text { con }}$ & at $2 \overline{0}^{\circ} \bar{C}$ & - & -- \\
\hline Control & $22.1 \mathrm{a}$ & 7.9ab & $2.8 \mathrm{abc}$ & - & - & - \\
\hline GA100 & $18.7 \mathrm{ab}$ & $6.3 \mathrm{c}$ & $2.9 \mathrm{ab}$ & - & - & - \\
\hline GA200 & 19.3ab & $6.3 c$ & $3.0 \mathrm{a}$ & - & - & - \\
\hline GA100 + BAP100 & $18.2 \mathrm{~b}$ & $7.0 \mathrm{bc}$ & $2.6 \mathrm{bc}$ & - & - & - \\
\hline BAP100 & $21.3 \mathrm{ab}$ & $8.6 a$ & $2.5 \mathrm{c}$ & - & - & - \\
\hline Significance & * & $* * *$ & $* *$ & - & - & - \\
\hline
\end{tabular}

Control: no hormones; GA100: GA 100 mg/L; GA200: GA 200 mg/L; GA100 + BAP100: GA 100 mg/L + BAP 100 mg/L; BAP100: BAP $100 \mathrm{mg} / \mathrm{L} .{ }^{\mathrm{z}}$ Means within columns followed by different letters are significantly different by Tukey's range test at $p<0.05 .{ }^{*}, * *, * * *$ significant at $p<0.05,0.01$, or 0.001 , respectively. Length:Width (L:W) ratio.

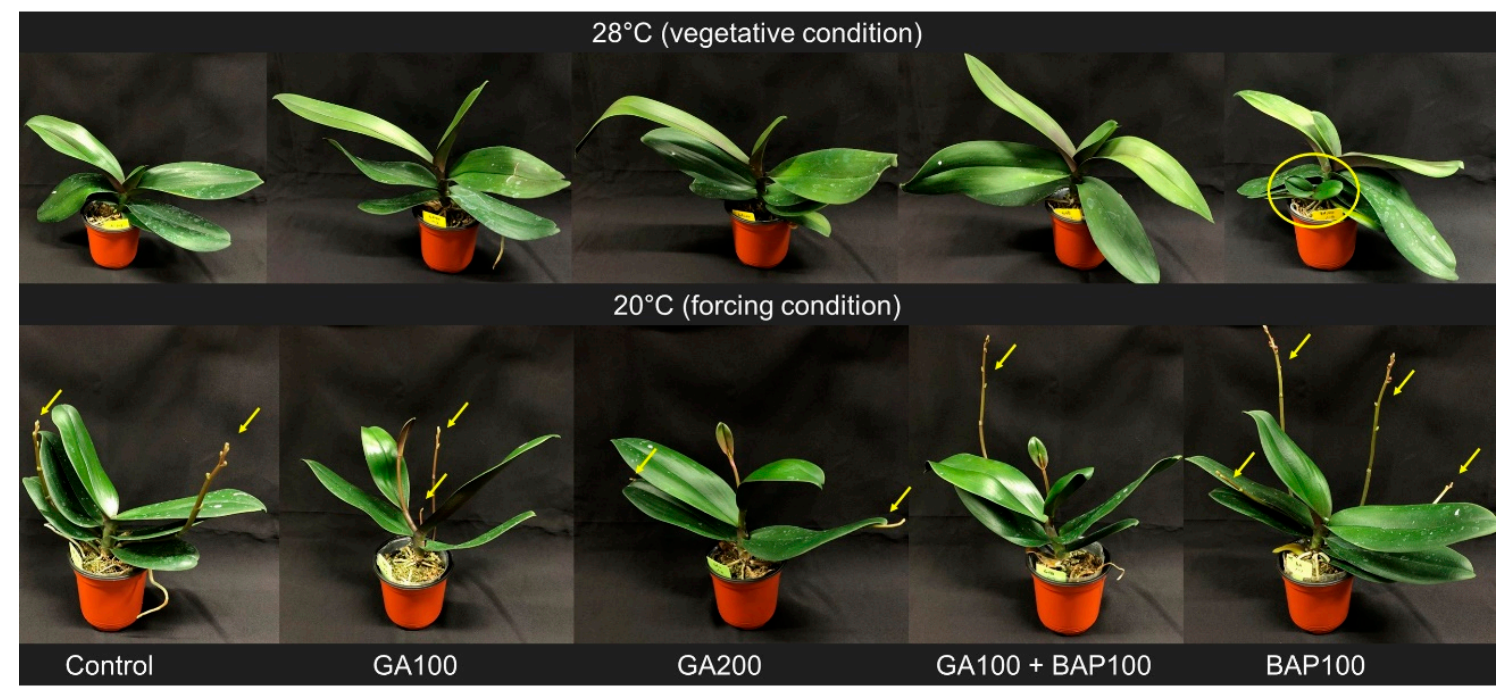

Figure 1. Growth and inflorescence emergence of Phalaenopsis Queen Beer 'Mantefon' plants treated with exogenous gibberellic acid ${ }_{3}\left(\mathrm{GA}_{3}\right)$ and 6-benzylaminopurine (BAP) at either $28^{\circ} \mathrm{C}$ (vegetative condition) or $20^{\circ} \mathrm{C}$ (forcing condition) for 15 weeks. Control: no hormones; GA100: GA 100 mg/L; GA200: GA 200 mg/L; GA100 + BAP100: GA 100 mg/L + BAP $100 \mathrm{mg} / \mathrm{L}$; BAP100: BAP $100 \mathrm{mg} / \mathrm{L}$. Circle and arrows indicate lateral shoot and inflorescences, respectively.

All exogenous hormonal treatments slightly increased the number of new leaves at $28{ }^{\circ} \mathrm{C}$ vegetative temperature, although there was no significant difference among treatments (Figure 2). The average new leaf numbers were largest in plants with $\mathrm{GA}_{3}$ + BAP. On the other hand, at $20^{\circ} \mathrm{C}$ forcing temperature, the average new leaf numbers significantly increased in $\mathrm{GA}_{3} 100 \mathrm{mg} / \mathrm{L}$ and $\mathrm{GA}_{3}+\mathrm{BAP}$ treatments compared with the no hormone and BAP alone ones.

\subsection{Inflorescence Initiation by Exogenous $G A_{3}$ and $B A P$ Treatment}

All exogenous hormonal treatments did not induce inflorescence initiation under the $28^{\circ} \mathrm{C}$ vegetative condition (Figure 1 ). Only BAP alone accelerated inflorescence emergence compared with the no hormone condition, while $\mathrm{GA}_{3}$ and $\mathrm{GA}_{3}+\mathrm{BAP}$ delayed the emergence and reduced the percentage of plants with inflorescences (Figure 3 ). The 
average days to visible inflorescence were $47.4,59.5,63.7,58.3$, and 42.9 in no hormone, $\mathrm{GA}_{3} 100 \mathrm{mg} / \mathrm{L}, \mathrm{GA}_{3} 200 \mathrm{mg} / \mathrm{L}, \mathrm{GA}_{3}+\mathrm{BAP}$, and BAP treatments, respectively.

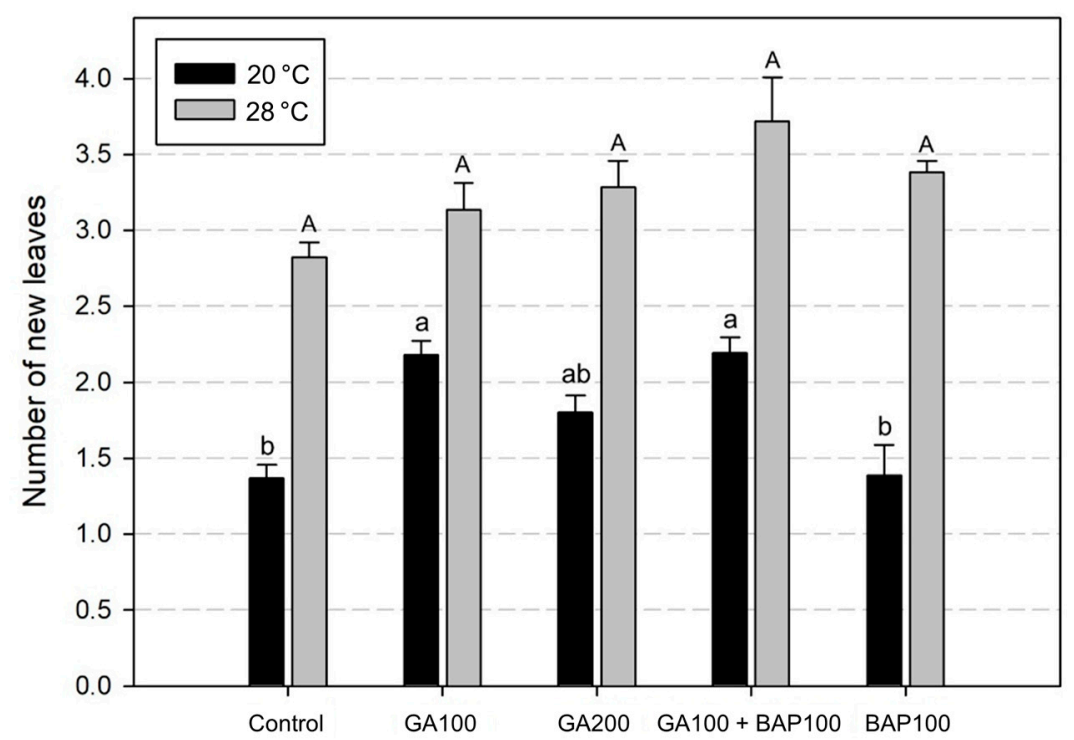

Figure 2. Number of new leaves of Phalaenopsis Queen Beer 'Mantefon' treated with exogenous gibberellic acid $_{3}\left(\mathrm{GA}_{3}\right)$ and 6-benzylaminopurine (BAP) at either $28^{\circ} \mathrm{C}$ (vegetative condition) or $2{ }^{\circ} \mathrm{C}$ (forcing condition) for 15 weeks. Control: no hormones; GA100: GA $100 \mathrm{mg} / \mathrm{L} ; \mathrm{GA} 200: \mathrm{GA}_{3}$ $200 \mathrm{mg} / \mathrm{L} ; \mathrm{GA} 100$ + BAP100: GA $100 \mathrm{mg} / \mathrm{L}$ + BAP 100 mg/L; BAP100: BAP $100 \mathrm{mg} / \mathrm{L}$. Different letters above bars are considered significant at $p<0.05$ by Tukey's honestly significant difference (HSD) test.

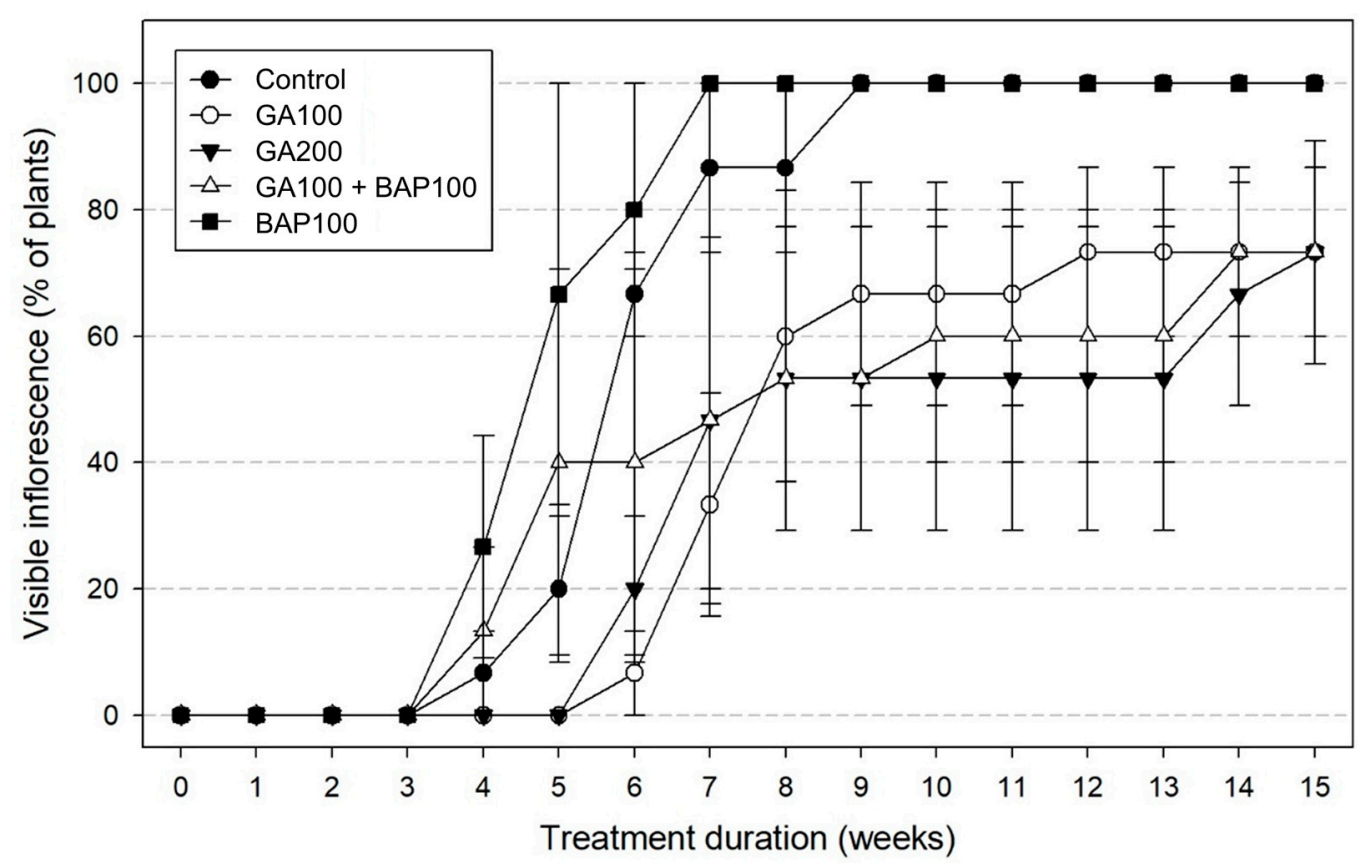

Figure 3. Percent of Phalaenopsis Queen Beer 'Mantefon' plants with visible inflorescence treated with exogenous gibberellic $\operatorname{acid}_{3}\left(\mathrm{GA}_{3}\right)$ and 6-benzylaminopurine (BAP) at $20^{\circ} \mathrm{C}$ forcing temperature. Control: no hormones; GA100: GA $3100 \mathrm{mg} / \mathrm{L}$; GA200: $\mathrm{GA}_{3} 200 \mathrm{mg} / \mathrm{L} ; \mathrm{GA} 100$ + BAP100: GA $100 \mathrm{mg} / \mathrm{L}+\mathrm{BAP} 100 \mathrm{mg} / \mathrm{L} ; \mathrm{BAP} 100:$ BAP $100 \mathrm{mg} / \mathrm{L}$.

Inflorescence numbers demonstrated opposite trends to the number of new leaves (Figures 2 and 4). BAP-treated showed significantly more inflorescence numbers than 
plants treated with $\mathrm{GA}_{3}$ and $\mathrm{GA}_{3}+\mathrm{BAP}$. Although there was no significant difference, a $50 \%$ increase was observed in BAP treatment compared with no hormone.

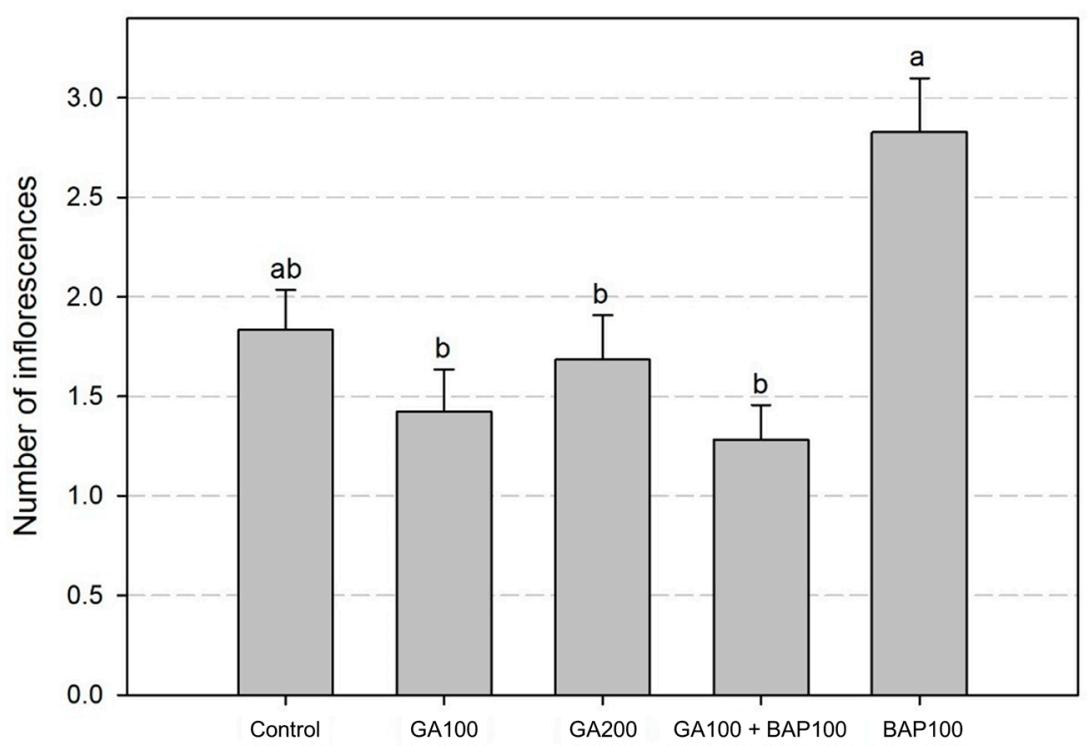

Figure 4. Number of inflorescences of Phalaenopsis Queen Beer 'Mantefon' plants treated with exogenous gibberellic acid $3\left(\mathrm{GA}_{3}\right)$ and 6-benzylaminopurine (BAP) at $20{ }^{\circ} \mathrm{C}$ forcing temperature for 15 weeks. Control: no hormones; GA100: GA 100 mg/L; GA200: GA 200 mg/L; GA100 + BAP100: $\mathrm{GA}_{3} 100 \mathrm{mg} / \mathrm{L}+\mathrm{BAP} 100 \mathrm{mg} / \mathrm{L}$; BAP100: BAP $100 \mathrm{mg} / \mathrm{L}$. Different letters above bars are considered significant at $p<0.05$ by Tukey's HSD test.

\section{Discussion}

Compared to the no hormone or BAP alone treatments under the $28^{\circ} \mathrm{C}$ vegetative condition, $\mathrm{GA}_{3}$ increased a $\mathrm{L}: \mathrm{W}$ ratio by increasing leaf length and decreasing leaf width. Given GA's role in vegetative elongation [8], these results are easily understood. In our previous study, an exogenous paclobutrazol, an anti-GA, reduced leaf length in Phalaenopsis [32]. Stem growth also showed similar responses. $\mathrm{GA}_{3}$ increased stem length but decreased stem diameter. However, when using $\mathrm{GA}_{3}$ and $\mathrm{BAP}$ together, the $\mathrm{GA}_{3}$ effects significantly weakened, although the $\mathrm{L}: \mathrm{W}$ ratio of plants with the $\mathrm{GA}_{3}+\mathrm{BAP}$ was still higher than for plants treated with the no hormone or BAP alone. GA and cytokinin (CK) are normally considered hormones that promote plant growth, but these hormones sometimes showed antagonistic effects on various developmental processes [33]. In tomato, for example, there was a negative interaction in hypocotyl elongation between plants treated with GA and BAP [34].

All exogenous hormonal treatments increased the number of new leaves. However, an abnormal increase in leaf and stem length by $\mathrm{GA}_{3}$ is not desirable in Phalaenopsis. In previous studies, mature Phalaenopsis plants generally showed a L:W ratio below $3.0[35,36]$. On the other hand, BAP increased new leave numbers with no significant difference in leaf shape (Table 1). The increase of leaf numbers by exogenous BAP treatment has been reported in many plants, including Dendrobium and Epipremnum [37,38]. CK-deficient transgenic tobacco plants showed decreasing leaf numbers [39]. Interestingly, a synergistic effect was observed in $\mathrm{GA}_{3}+\mathrm{BAP}$ treatment compared with $\mathrm{GA}_{3}$ or BAP alone. Although there was no significance, the increase of approximately 0.9 in the number of new leaves was a remarkable difference, considering the slow growth of Phalaenopsis plants. Because Phalaenopsis develops inflorescence meristem at the base of each leaf in stem [5], the number of new leaves is an important indicator for vegetative growth. Exogenous hormonal application has not been used for commercial Phalaenopsis production yet, but the growthpromoting effects by a balanced use of GA and CK can give new insights into improvement of Phalaenopsis cultivation. 
Contrary to results at $28{ }^{\circ} \mathrm{C}$, relatively little differences in leaf shape among treatment groups were observed at the $20^{\circ} \mathrm{C}$ forcing temperature. It could be attributed to the growth characteristics during reproductive development. In Phalaenopsis, inflorescence is a developing organ during the reproductive period at forcing temperature, whereas vegetative development mainly occurs at high temperatures [40].

$\mathrm{GA}_{3}$ and $\mathrm{GA}_{3}+\mathrm{BAP}$ slightly increased a L:W ratio at the forcing temperature, but the leaves were shorter than for the no hormone or BAP alone, unlike the results at $28{ }^{\circ} \mathrm{C}$, indicating that plants treated with $\mathrm{GA}_{3}$ under forcing condition developed small leaves. The $\mathrm{GA}_{3}$ increased the number of new leaves. Assimilates are partitioned by the 'source-sink' relationship [41]. Since a newly developing leaf is the main 'sink' organ in Phalaenopsis [42], increasing new leaf numbers could limit leaf growth. In previous studies, GAs promoted sucrose translocation from 'source' leaves to 'sink' organs [43,44]. Also, in perennials, exogenous GA treatment can prevent transition from the vegetative to reproductive stage by promoting vegetative organs like leaves and roots [11]. In this study, the inflorescence emergence was delayed by $\mathrm{GA}_{3}$ and $\mathrm{GA}_{3}+$ BAP treatments (Figure 3).

Previous studies reported that exogenous BAP treatment enhanced inflorescence emergence and this promotive effect increased with increasing BAP concentrations in Phalaenopsis [25,27]. In this study, BAP also increased inflorescence numbers (Figure 4). CK can play a role as a stimulus for floral transition [20]. In Arabidopsis, CK induced transcriptional activation of a paralogue of FLOWERING LOCUS T (FT), TWIN SISTER OF FT (TSF) [22]. Also, exogenous CK treatment could induce the biosynthesis of endogenous CKs $[45,46]$. In general, Phalaenopsis inflorescences at the leaf axil of the third or fourth nodes from apical leaf are differentiated during inflorescence initiation [4]. BAP spray could induce more inflorescences below the fourth nodes [25,47]. However, GA $3+$ BAP did not increase inflorescence number (Figure 4). This result is consistent with a study by Blanchard and Runkle [25]. It indicated that the addition of GA attenuated the promotive effect of $\mathrm{BAP}$ in inflorescence emergence. Also, in this study, $\mathrm{GA}_{3}$ alone elicited no promotion in inflorescence initiation, irrespective of solution concentrations.

Huang et al. [18] reported that DELLA genes were suppressed, and floral pathway integrator genes were upregulated by cool temperature exposure in Phalaenopsis, indicating that the GA pathway may be involved in floral transition. However, in a previous study, upregulations of genes related to GA biosynthesis were not identified under forcing condition [19]. In addition, inflorescence initiation by $\mathrm{GA}_{4+7}$ injection was not observed at vegetative high temperature [17]. In this study, exogenous $\mathrm{GA}_{3}$ treatments also had no effect on the substitution of a low-temperature exposure (Figure 1). However, in our previous study, anti-GA (paclobutrazol) drenching inhibited the inflorescence initiation under forcing condition [32]. Low-temperature exposure is necessary for GA to be active in floral transition even though it is involved in Phalaenopsis inflorescence initiation. Exogenous GA treatment could induce flowering in vernalization-requiring or long-day plants $[11,48,49]$. Although Phalaenopsis also requires a temperature drop for inflorescence initiation, its effective temperature ranges from 15 to $25^{\circ} \mathrm{C}$ and is higher than for other vernalization-requiring plants $[4,50]$. Furthermore, this plant is regarded as a short-day or day-neutral plant [51-53]. Considering these flowering responses to temperature and photoperiod, it would be expected that the GA pathway is not the main factor in controlling floral transition of Phalaenopsis.

Exogenous BAP treatment at $28{ }^{\circ} \mathrm{C}$ vegetative temperature also did not induce inflorescence initiation (Figure 1). Under vegetative high-temperature condition, CKs were converted from active to inactive forms in Phalaenopsis [24]. Because several weeks of a prolonged forcing period are required for inflorescence initiation, the action of exogenous BAP would not last long enough. On the other hand, in Dendrobium, which similarly requires low-temperature exposure for floral transition, exogenous CK could induce inflorescence initiation [23]. Therefore, it is necessary to determine whether the substitution of low-temperature exposure is possible through repeated BAP treatments. 
On the other hand, lateral shoots were observed in BAP-treated plants under vegetative condition (Figure 1). Maintenance of shoot apical meristem is normally regulated by a crosstalk between auxin and CK [54]. CK is directly involved in the outgrowth of axillary buds [55], and auxin inhibits the development of axillary buds by repressing CK biosynthesis [56]. Phalaenopsis develops two bud primordia at each node during vegetative growth period: one can be differentiated to inflorescence and the other to vegetative bud [5]. The newly developed shoots might be differentiated from the vegetative bud by the BAP treatment.

Unlike other sympodial orchids such as Cymbidium, Oncidium, etc., Phalaenopsis is a monopodial orchid. Single stem has a limitation in producing a lot of inflorescences. Because the number of inflorescences is an important indicator of commercial quality in Phalaenopsis production, multiple shoots can increase its horticultural value by the potential to make many inflorescences. To our knowledge, no data has been published about induction of multiple shoots by exogenous CK treatment during a vegetative cultivation period. Therefore, from the results of this study, further research is required to identify the detailed method for multi-shoot Phalaenopsis production.

\section{Conclusions}

In this study, we observed the effects of exogenous application of $\mathrm{GA}_{3}$ and BAP on leaf development and on changes of leaf and stem shapes in Phalaenopsis. Interestingly, BAP induced the development of lateral shoots even though this plant is a monopodial orchid. Although the exogenous hormonal application at vegetative high temperature could not substitute for a low-temperature exposure in floral transition, BAP treatment under forcing condition accelerated inflorescence emergence and increased inflorescence numbers. These findings can be of help to use the growth-promoting hormones on quality Phalaenopsis production.

Author Contributions: K.S.K. and H.B.L. conceived and designed the study. H.B.L. and N.H.I. carried out the experiments. H.B.L. and S.K.A. analyzed the data. All authors contributed to data interpretation. H.B.L. wrote the manuscript. K.S.K. provided guidance on the whole study and improved the manuscript. All authors have read and agreed to the published version of the manuscript.

Funding: This research was funded by the National Research Foundation of Korea (NRF) (grant No. NRF-2017R1A2B4009411).

Institutional Review Board Statement: Not applicable.

Informed Consent Statement: Not applicable.

Data Availability Statement: The data presented in this study are available on request from the corresponding author.

Acknowledgments: The authors are thankful to the National Research Foundation of Korea (NRF) for the grant funded by the Korean government (MSIT) (No. NRF-2017R1A2B4009411).

Conflicts of Interest: The authors declare no conflict of interest.

\section{References}

1. Chen, W.H.; Chen, H.H. Orchid Biotechnology II, 1st ed.; World Scientific Publishing Co. Pte. Ltd.: Singapore, 2011.

2. De, L.C.; Pathak, R.; Rao, A.N.; Rajeevan, P.K. Commercial Orchids; Walter de Gruyter GmbH: Berlin, Germany, 2014.

3. Christenson, E.A. Phalaenopsis: A Monograph; Timber Press: Portland, OR, USA, 2001.

4. Sakanishi, Y.; Imanishi, H.; Ishida, G. Effect of temperature on growth and flowering of Phalaenopsis amabilis. Bull. Univ. Osaka Prefect. Ser. B Agr. Biol. 1980, 32, 1-9.

5. Rotor, G.B. Daylength and temperature in relation to growth and flowering of orchids. Cornell Univ. Agr. Exp. Sta. Bull. 1952, $885,3-45$.

6. Dueck, T.; Trouwborst, G.; Hogewoning, S.W.; Meinen, E. Can a high red: Far red ratio replace temperature-induced inflorescence development in Phalaenopsis? Environ. Exp. Bot. 2016, 121, 139-144. [CrossRef] 
7. Runkle, E.S. Environmental and hormonal regulation of flowering in Phalaenopsis orchids: A mini review. Acta Hortic. 2010, 878, 263-267. [CrossRef]

8. Fleet, C.M.; Sun, T.-P. A DELLAcate balance: The role of gibberellin in plant morphogenesis. Curr. Opin. Plant Biol. 2005, 8, 77-85. [CrossRef]

9. Kucera, B.; Cohn, M.A.; Leubner-Metzger, G. Plant hormone interactions during seed dormancy release and germination. Seed Sci. Res. 2005, 15, 281-307. [CrossRef]

10. Wang, Y.H.; Irving, H.R. Developing a model of plant hormone interactions. Plant Signal. Behav. 2011, 6, 494-500. [CrossRef]

11. Mutasagottgens, E.S.; Hedden, P. Gibberellin as a factor in floral regulatory networks. J. Exp. Bot. 2009, 60, 1979-1989. [CrossRef]

12. Jung, H.; Jo, S.H.; Jung, W.Y.; Park, H.J.; Lee, A.; Moon, J.S.; Seong, S.Y.; Kim, J.-K.; Kim, Y.-S.; Cho, H.S. Gibberellin Promotes Bolting and Flowering via the Floral Integrators RsFT and RsSOC1-1 under Marginal Vernalization in Radish. Plants 2020, 9, 594. [CrossRef]

13. Bao, S.; Hua, C.; Shen, L.; Yu, H. New insights into gibberellin signaling in regulating flowering in Arabidopsis. J. Integr. Plant Biol. 2020, 62, 118-131. [CrossRef]

14. Chen, W.-S.; Liu, H.-Y.; Liu, Z.-H.; Yang, L.; Chen, W.-H. Gibberellin and temperature influence carbohydrate content and flowering in Phalaenopsis. Physiol. Plant. 1994, 90, 391-395. [CrossRef]

15. Chen, W.-S.; Chang, H.-W.; Chen, W.-H.; Lin, Y.-S. Gibberellic Acid and Cytokinin Affect Phalaenopsis Flower Morphology at High Temperature. HortScience 1997, 32, 1069-1073. [CrossRef]

16. Su, W.-R.; Chen, W.-S.; Koshioka, M.; Mander, L.N.; Hung, L.-S.; Chen, W.-H.; Fu, Y.-M.; Huang, K.-L. Changes in gibberellin levels in the flowering shoot of Phalaenopsis hybrida under high temperature conditions when flower development is blocked. Plant Physiol. Biochem. 2001, 39, 45-50. [CrossRef]

17. Wang, Y.-T. Gibberellic acid on Phalaenopsis. Am. Orchid Soc. Bull. 1995, 64, 744.

18. Huang, J.-Z.; Lin, C.-P.; Cheng, T.-C.; Huang, Y.-W.; Tsai, Y.-J.; Cheng, S.-Y.; Chen, Y.-W.; Lee, C.-P.; Chung, W.-C.; Chang, B.C.-H.; et al. The genome and transcriptome of Phalaenopsis yield insights into floral organ development and flowering regulation. Peer 2016, 4, e2017. [CrossRef] [PubMed]

19. Qin, Q.; Kaas, Q.; Zhang, C.; Zhou, L.; Luo, X.; Zhou, M.; Sun, X.; Zhang, L.; Paek, K.-Y.; Cui, Y. The Cold Awakening of Doritaenopsis 'Tinny Tender' Orchid Flowers: The Role of Leaves in Cold-induced Bud Dormancy Release. J. Plant Growth Regul. 2012, 31, 139-155. [CrossRef]

20. Bernier, G. My favourite flowering image: The role of cytokinin as a flowering signal. J. Exp. Bot. 2013, 64, 5795-5799. [CrossRef]

21. Tarkowská, D.; Filek, M.; Biesaga-Kościelniak, J.; Marcińska, I.; Macháčková, I.; Krekule, J.; Strnad, M. Cytokinins in shoot apices of Brassica napus plants during vernalization. Plant Sci. 2012, 187, 105-112. [CrossRef]

22. D'Aloia, M.; Bonhomme, D.; Bouché, F.; Tamseddak, K.; Ormenese, S.; Torti, S.; Coupland, G.; Périlleux, C. Cytokinin promotes flowering of Arabidopsis via transcriptional activation of the FT paralogue TSF. Plant J. 2011, 65, 972-979. [CrossRef]

23. Wen, Z.; Guo, W.; Li, J.; Lin, H.; He, C.; Liu, Y.; Zhang, Q.; Liu, W. Comparative Transcriptomic Analysis of Vernalization- and Cytokinin-Induced Floral Transition in Dendrobium nobile. Sci. Rep. 2017, 7, srep45748. [CrossRef]

24. Chou, C.C.; Chen, W.-S.; Huang, K.-L.; Yu, H.-C.; Liao, L.-J. Changes in cytokinin levels of Phalaenopsis leaves at high temperature. Plant Physiol. Biochem. 2000, 38, 309-314. [CrossRef]

25. Blanchard, M.G.; Runkle, E.S. Benzyladenine Promotes Flowering in Doritaenopsis and Phalaenopsis Orchids. J. Plant Growth Regul. 2008, 27, 141-150. [CrossRef]

26. Wu, P.-H.; Chang, D.C. The Use of N-6-benzyladenine to Regulate Flowering of Phalaenopsis Orchids. HortTechnology 2009, 19, 200-203. [CrossRef]

27. An, H.R.; Lee, S.Y.; Park, P.H.; Park, P.M.; Yun, D.L. 6-Benzylaminopurine Influences Flower Quality of Miniature Phalaenopsis and Doritaenopsis Orchids. Flower Res. J. 2017, 25, 216-222. [CrossRef]

28. Chen, Y.; Piluek, C. Effects of thidiazuron and N6-benzylaminopurine on shoot regeneration of Phalaenopsis. Plant Growth Regul. 1995, 16, 99-101. [CrossRef]

29. Ishii, Y.; Takamura, T.; Goi, M.; Tanaka, M. Callus induction and somatic embryogenesis of Phalaenopsis. Plant Cell Rep. 1998, 17, 446-450. [CrossRef] [PubMed]

30. Tokuhara, K.; Mii, M. Micropropagation of Phalaenopsis and Doritaenopsis by culturing shoot tips of flower stalk buds. Plant Cell Rep. 1993, 13, 7-11. [CrossRef] [PubMed]

31. Dueck, T.; Hogewoning, S.W.; Pot, S.; Meinen, E.; Trouwborst, G.; Kempkes, F. Stuurlicht in de Glastuinbouw: 1. Kansen voor Energiebesparing? Wageningen UR Glastuinbouw: Bleiswijk, The Netherlands, 2015.

32. Lee, H.B.; Kim, K.S. Growth and inflorescence initiation of Phalaenopsis orchids by paclobutrazol treatment. Flower Res. J. 2020, accepted.

33. Weiss, D.; Ori, N. Mechanisms of Cross Talk between Gibberellin and Other Hormones. Plant Physiol. 2007, 144, 1240-1246. [CrossRef] [PubMed]

34. Fleishon, S.; Shani, E.; Ori, N.; Weiss, D. Negative reciprocal interactions between gibberellin and cytokinin in tomato. New Phytol. 2011, 190, 609-617. [CrossRef]

35. An, S.K.; Kim, Y.J.; Kim, K.S. Optimum heating hour to maintain vegetative growth and inhibit premature inflorescence initiation of six-month and one-year-old Phalaenopsis hybrids. Hortic. Environ. Biotechnol. 2013, 54, 91-96. [CrossRef] 
36. Van Noort, F.; Dueck, T. Influence of fertilization and a high daily light integral on the growth and flowering of Phalaenopsis. Acta Hortic. 2015, 1078, 93-98. [CrossRef]

37. Benedetto, A.; Galmarini, C.R.; Tognetti, J. Changes in leaf size and in the rate of leaf production contribute to cytokinin-mediated growth promotion in Epipremnum aureum L. cuttings. J. Hortic. Sci. Biotechnol. 2013, 88, 179-186. [CrossRef]

38. Nambiar, N.; Siang, T.C.; Mahmood, M. Effect of 6-benzylaminopurine on flowering of a Dendrobium orchid. AJCS 2012, 6 , 225-231.

39. Werner, T.; Motyka, V.; Strnad, M.; Schmülling, T. Regulation of plant growth by cytokinin. Proc. Natl. Acad. Sci. USA 2001, 98, 10487-10492. [CrossRef] [PubMed]

40. Lee, H.B.; Jeong, S.J.; Lim, N.H.; An, S.K.; Kim, K.S. Correlation between carbohydrate contents in the leaves and inflorescence initiation in Phalaenopsis. Sci. Hortic. 2020, 265, 109270. [CrossRef]

41. Gifford, R.M.; Evans, L.T. Photosynthesis, Carbon Partitioning, and Yield. Annu. Rev. Plant Physiol. 1981, 32, 485-509. [CrossRef]

42. Susilo, H.; Peng, Y.-C.; Lee, S.-C.; Chen, Y.-C.; Chang, Y.-C.A. The Uptake and Partitioning of Nitrogen in Phalaenopsis Sogo Yukidian 'V3' as Shown by ${ }^{15} \mathrm{~N}$ as a Tracer. J. Am. Soc. Hortic. Sci. 2013, 138, 229-237. [CrossRef]

43. Aloni, B.; Daie, J.; Wyse, R.E. Enhancement of $\left[{ }^{14} \mathrm{C}\right]$ Sucrose Export from Source Leaves of Vicia faba by Gibberellic Acid. Plant Physiol. 1986, 82, 962-966. [CrossRef]

44. Iqbal, N.; Nazar, R.; Khan, M.I.R.; Masood, A.; Khan, N.A. Role of gibberellins in regulation of source-sink relations under optimal and limiting environmental conditions. Curr. Sci. 2011, 100, 998-1007.

45. Letham, D.S. Cytokinins as phytohormones-Sites of biosynthesis, translocation, and fuction of translocated cytokinin. In Cytokinins: Chemistry, Activity, and Function; Mok, D.W.S., Mok, M.C., Eds.; CRC Press: Boca Raton, FL, USA, $1994 ;$ pp. 57-80.

46. Rossi, G.; Marziani, G.P.; Uneddu, P.; Longo, C.P. Changes in endogenous levels of three cytokinins during development of excised watermelon cotyledons. Physiol. Plant. 1991, 83, 647-651. [CrossRef]

47. Yoneda, K.; Momose, H. Effects on flowering of Phalaenopsis caused by spraying growth regulators when transferred to highlands. Bull. Coll. Agric. Vet. Med. Nihon Univ. 1990, 47, 71-74.

48. Michniewicz, M.; Lang, A. Effect of nine different gibberellins on stem elongation and flower formation in cold-requiring and photoperiodic plants grown under non-inductive conditions. Planta 1962, 58, 549-563. [CrossRef]

49. Ohkawa, K. Effects of gibberellins and benzyladenine on dormancy and flowering of Lilium speciosum. Sci. Hortic. 1979, 10, 255-260. [CrossRef]

50. Chouard, P. Vernalization and its Relations to Dormancy. Annu. Rev. Plant Physiol. 1960, 11, 191-238. [CrossRef]

51. Jang, S.; Choi, S.-C.; Li, H.-Y.; An, G.; Schmelzer, E. Functional Characterization of Phalaenopsis aphrodite Flowering Genes PaFT1 and PaFD. PLoS ONE 2015, 10, e0134987. [CrossRef] [PubMed]

52. Lee, H.B.; Lee, J.H.; An, S.K.; Park, J.H.; Kim, K.S. Growth characteristics and flowering initiation of Phalaenopsis Queen Beer 'Mantefon' as affected by the daily light integral. Hortic. Environ. Biotechnol. 2019, 60, 637-645. [CrossRef]

53. Lopez, R.G.; Runkle, E.S. Environmental Physiology of Growth and Flowering of Orchids. HortScience 2005, 40, 1969-1973. [CrossRef]

54. Azizi, P.; Rafii, M.Y.; Maziah, M.; Abdullah, S.N.A.; Hanafi, M.M.; Latif, M.A.; Rashid, A.A.; Sahebi, M. Understanding the shoot apical meristem regulation: A study of the phytohormones, auxin and cytokinin, in rice. Mech. Dev. 2015, 135, 1-15. [CrossRef]

55. Cline, M.G. Apical dominance. Bot. Rev. 1991, 57, 318-358. [CrossRef]

56. Tanaka, M.; Takei, K.; Kojima, M.; Sakakibara, H.; Mori, H. Auxin controls local cytokinin biosynthesis in the nodal stem in apical dominance. Plant J. 2006, 45, 1028-1036. [CrossRef] [PubMed] 